\title{
A promising method to control ragweed Ambrosia artemisiifolia L. in urban cenoses
}

\author{
Leonid Esipenko ${ }^{1,}{ }^{*}$ and Almaskhan Ketsba ${ }^{2}$ \\ ${ }^{1}$ Federal Research Center of Biological Plant Protection, 350039, Krasnodar, 39, Russia \\ ${ }^{2}$ Institute of Agriculture of the Academy of Sciences of Abkhazia, Sukhum, Republic of Abkhazia
}

\begin{abstract}
Invasions of adventive weed species are one of the leading factors in the transformation of agrobiocenoses and urban cenoses. Naturalization of new species leads to serious ecological, social and economic consequences. One of the dangerous invasive plants is ragweed (Ambrosia artemisiifolia L.), which is widespread in many countries of the world, including Russia. This weed plant causes significant economic damage and harmful impact on human health, since its pollen is a strong allergen. Modern technologies of agricultural production do not always give positive results in the fight against this plant. Therefore, it is necessary to develop new ecologically low-hazard methods to control it, aimed at reducing the productivity of pollen and seeds in order to reduce allergic diseases among people and limit the expansion of its range.
\end{abstract}

\section{Introduction}

A large number of publications by domestic and foreign authors are devoted to biological invasions. The spread of adventive species in the world causes a global threat to modern biogeocenoses and is the most important problem in modern biology. A number of works are devoted to the reasons for the spread of adventive (alien) species, where considerable attention is paid to the consequences of their introduction into recipient ecosystems $[1,2,3,4,5,6,7]$.

In places of invasion, adventive species form "biological pollution", this term refers to their reproduction in new conditions [8], which negatively affects species diversity, stability and functioning of ecosystems [9]. In this regard, invasions of adventive species are considered one of the leading factors in the transformation of ecosystems that have taken place in recent decades as a result of the intensification of human economic activity [10]. Particularly strong violations of the structural and functional organization are caused by adventive species in agroecosystems, since, having a sufficient breadth of adaptive potential, they are actively introduced into plant communities disturbed by soil cultivation. This affects the phytosanitary state of agroecosystems and leads to serious environmental, social and economic consequences. It is known that crop yield losses caused by adventive species amount up to 9-19\% in the world and amount up to billions of dollars annually [11].

* Corresponding author: esipenkol@yandex.ru 
Prevention of the spread of adventive species is a priority direction of human activity in the field of environmental safety. Large international symposia, conferences and congresses are devoted to this problem, the main solutions of which are focused on the development of national programs for the effective management of populations of adventive species in various habitats. The need to monitor the spread of adventive species and prevent biological pollution of ecosystems is reflected in the International Convention on Biological Diversity (1992) and in the international Global Invasive Species Program (1997) [12]. Within the framework of this program, the Global Invasive Species Datebasa, GIBD, 2001) was created, which contains information on the biology and distribution of "100 dangerous" adventive species that negatively affect the biodiversity of ecosystems, the economy and human health.

Among the adventive species included in the Global Database, ragweed (Ambrosia artemisiifolia L.), which is widespread in many countries of the world, is included. This weed plant, in addition to economic damage, causes significant harm to human health, since the pollen produced is a strong allergen. The total cost of the negative impact of ragweed on human health and crop yields in the EU countries is estimated at 4.5 billion euros per year [13].

As a result of our research, two development strategies have been identified in ragweed. The first type is observed in the first year of growth, after a violation of the biocenosis, the plant grows upward, capturing all the free space. The second type is associated with mechanical action on ragweed by mowing the plant. As a result of such damage, new type of shoots (modules) appear in ragweed.

Mowing of weeds in urban areas is carried out regularly, regardless of what phenological phase ragweed is in. The main task is to destroy weeds in the urban community. Early mowing of ragweed leads to regrowth and instead of one main stem, several appear, which increases the production of pollen and seeds. Late mowing, after the flowering phase, leads to widespread distribution of weed seeds. Thus, the planned mowing of weeds does not always lead to a positive result. The selection of the optimal mowing time is a difficult task that has not been previously studied. At the same time, the influence of mowing regimes on the development of ragweed is well studied $[14,15,16,17]$. The difficulty in determining the timing of the physical destruction of the vegetative mass is associated with its physiological characteristics of the development of male and female flowers.

The aim of our research was to study the physiological characteristics of $A$. artemisiifolia in order to determine the optimal modes of mowing of ragweed and its vegetative mass, and to prevent it from producing pollen and seed infection.

\section{Material and methods}

The work was carried out under the conditions of a growing house in Krasnodar Krai. 4 wooden boxes with soil 50x30x40 cm were prepared. In each box, 27 ragweed plants with different phases of vegetative development were planted in order to create natural growing conditions.

Mowing of ragweed plants was carried out with scissors at a height of $3 \mathrm{~cm}$ above ground level in three period steps. The first cut was carried out on June 8 in the phase of 610 true leaves, the second on July 15 (12-16 true leaves), the third on August 10 (beginning of flowering). At the end of the experiment, the plants were weighed and the number of seeds was counted. 


\section{Results and discussion}

Ragweed is a quarantine plant in Russia, which has naturalized in natural and anthropogenic ecosystems in various soil and climatic zones. Modern technologies for controlling weeds, including quarantine ones, often do not give positive results. In agrobiocenoses, ragweed is a plant dominant. In the field crop rotation, it inhibits mainly row crops, the losses of which reach up to $60-70 \%$ of the yield [18]. It is not possible to effectively control ragweed due to its biological characteristics [19]. An introduction from North America of the biological agents Zygogramma. suturalis (F.) (Coleoptera: Chrysomelidae) and Tarachidia. candefacta Hubn. ((Lepidoptera: Noctuidae) was unsuccessful against $A$. artemisiifolia [20].

The synthesis of modern herbicides and their use in full do not destroy A. artemisiifolia on row crops, in particular on sunflower [21]. The use of herbicides in urban areas is prohibited because they have a negative impact on the environment. Ragweed, like other weeds during the development of world agriculture, has developed resistance to herbicides [22]. To study the mechanism of their resistance to herbicides, a special committee HRAC (Herbicide Resistance Action Committee), www.weedscience.org, was created. [23.24].

Urban cenoses are temporary communities, and they are represented by complex combinations of natural, man-made and architectural forms, places of work and rest of the residents. The constant anthropogenic impact on the phytocenosis leads to a failure of biocenotic self-regulation, and the spread of ragweed. During the flowering period of ragweed, pollen produced by the plant causes a serious illness in humans - allergic rhinitis. According to the data provided by the Krasnodar Krai Allergy Center, an increase in the number of sick residents is currently observed. In the last three years alone, their number has increased by 10 thousand people.

The lack of effective methods for controlling A. artemisiifolia and the observed climate warming led to a tendency to expand its range from the places of invasion in the eastern and northern directions. The use of herbicides often does not give positive results due to economic feasibility and environmental safety. Agrotechnical method of controlling ragweed by mowing it is one of the most promising.

As a result of the first cutting of the vegetative mass of ragweed, the growth energy sharply decreased. Due to the physiological characteristics of the weed plant, its ability to form modules, the mechanism of regeneration of the vegetative mass was observed. From 4 to 7 actively growing side shoots were noted (Table 1 )..

Table 1. Influence of A. artemisiifolia mowing on plant height in different phases of development.

\begin{tabular}{|c|c|c|c|c|c|}
\hline Mowing & $\begin{array}{c}\text { Number of } \\
\text { plants, pcs. }\end{array}$ & $\begin{array}{c}\text { Average plant } \\
\text { height, cm. }\end{array}$ & $\begin{array}{c}\text { Min. } \\
\text { height, } \\
\text { cm. }\end{array}$ & $\begin{array}{c}\text { Max. height, } \\
\text { cm }\end{array}$ & $\begin{array}{c}\% \\
\text { regeneration }\end{array}$ \\
\hline Control & 27 & $65,70 \pm 4,81$ & 25 & 100 & - \\
\hline First cut & 27 & $27,07 \pm 2,53$ & 10 & 55 & 41 \\
\hline Second cut & 27 & $16,81 \pm 0,91$ & 10 & 25 & 62 \\
\hline Third cut & 27 & $12,25 \pm 0,74$ & 7 & 20 & 73 \\
\hline
\end{tabular}

Shoot regeneration occurs due to the activation of growth points (dormant buds). Within 40 days, the plant fully regains its reproductive potential, and the vegetative mass is renewed by $40 \%$ from the control plants.

After the second cut, ragweed regains its vegetative mass by $62 \%$ of the vegetative mass of plants of the first cut. The third cut allows ragweed to recover only $73 \%$ of the vegetative mass of the second cut. Consequently, three-time mowing of ragweed reduces the vegetative mass of the plant. 
The data obtained indicate that, despite the total loss of aboveground biomass after the first and second cuts, the recovery mechanisms provide a full regeneration of $A$. artemisiifolia

The reduction in vegetation mass as a result of mowing ragweed is not the main factor in the decrease in the production of allergenic pollen and seeds. It is known that the male inflorescences of $A$. artemisiifolia, producing a large amount of pollen, are the first to bloom, and then the female ones. In this regard, in ragweed plants, after each cut, we counted male inflorescences and female flowers (Table 2).

Table 2. The effect of ragweed mowing on the number of male inflorescences/

\begin{tabular}{|l|l|l|l|l|c|}
\hline Mowing & $\begin{array}{l}\text { Number } \\
\text { of plants, } \\
\text { pcs. }\end{array}$ & $\begin{array}{l}\text { Average number } \\
\text { of male } \\
\text { inflorescences, } \\
\text { pcs. }\end{array}$ & $\begin{array}{l}\text { Min. number of } \\
\text { male } \\
\text { nflorescences, } \\
\text { pcs. }\end{array}$ & $\begin{array}{l}\text { Max. number of } \\
\text { male } \\
\text { inflorescences, } \\
\text { pcs. }\end{array}$ & $\begin{array}{l}\% \\
\text { regeneratio } \\
\mathrm{n}\end{array}$ \\
\hline Control & 27 & $1897,59 \pm 120,92$ & 725 & 2610 & \\
\hline First cut & 27 & $644,55 \pm 64,69$ & 270 & 1100 & 33 \\
\hline Second cut & 27 & $251,85 \pm 16,66$ & 120 & 420 & 38 \\
\hline Third cut & 27 & $29,96 \pm 2,84$ & 15 & 46 & 11 \\
\hline
\end{tabular}

The data obtained indicate the effect of mowing on the pollen produced by male inflorescences. The restoration of the vegetative mass in ragweed after the first, second and third cuts proceeds quickly, the mechanism of the formation of male inflorescences decreases, the biological resource of the plant for the restoration of reproductive organs is not enough.

The number of female flowers after A. artemisiifolia mowing also decreases. As can be seen from Table 3, their maximum number reached 34 flowers.

Table 3. The effect of ragweed mowing ragweed on the number of female flowers

\begin{tabular}{|l|c|c|c|c|c|}
\hline Mowing & $\begin{array}{l}\text { Number } \\
\text { of plants, } \\
\text { pcs. }\end{array}$ & $\begin{array}{l}\text { Average number of } \\
\text { female flowers, pcs. }\end{array}$ & $\begin{array}{l}\text { Min. number } \\
\text { of female } \\
\text { flowers, pcs. }\end{array}$ & $\begin{array}{l}\text { Max. number female } \\
\text { of flowers, pcs. }\end{array}$ & $\begin{array}{c}\% \\
\text { regenerati } \\
\text { on }\end{array}$ \\
\hline Control & 27 & $172,62 \pm 9,66$ & 67 & 237 & - \\
\hline First cut & 27 & $67,59 \pm 4.54$ & 35 & 110 & 38 \\
\hline Second cut & 27 & $25,481,65$ & 13 & 35 & 37 \\
\hline Third cut & 27 & $11,62 \pm 1,14$ & 6 & 34 & 44 \\
\hline
\end{tabular}

This leads to a decrease in seed productivity in ragweed. It is important to note the fact that the restoration of female flowers in a plant is much more active in contrast to male ones. This is due to the physiological characteristics of A. artemisiifolia, to preserve the reproductive activity of the plant.

\section{Conclusions}

Based on the conducted research, it can be concluded that in order to reduce the pollen and seed productivity of ragweed, it is necessary to carry out 3 mechanical actions to destroy the vegetative mass: in the phase of 6-10 true leaves, 12-16 and during the beginning of flowering.

The research was carried out in accordance support of the FSBI "RFBR" and the Administration of Krasnodar Krai as part of the projects - superviser № 20 -416-235006 


\section{References}

1. H.A. Mooney, J.A Drake, Springer-Verlag, New York, (1986)

2. Vitousek, P. Ecology (1994)

3. J.A. McNeely, H.A. Mooney, L.E. Neville, P. Schei, J. K. Waage, Global Strategy on Invasive Alien Species.IUCN (2001)

4. F.D. Panetta, O. Cacho, S. Hester, N. Sims-Chilton, Brooks, S. J. Applied Ecol. (2011)

5. D. Pimentel, S. McNair, J. Janecka, J. Wightman, C. Simmonds, C. O’Connell, E. Wong, L. Russel, J. Zern, T. Aquino, T. Tsomondo, J.Agriculture, Ecosystems, and Environment (2001)

6. E. Leppakoski, P. Gruszka, H. Ojaveer, S. Olenin, V. Panov, Can. J. Fish. Aquat. Sci. (2002).

7. C.F. Musil, S.J. Milton, G.W Davis, J. South African of Science (2005)

8. M. Eliot, Marine Pollution Bulletin (2003).

9. V.H Heywood, In: Biological Invasions: a Global Perspective (1989)

10. G.H. Rodda,., Y. Sawai, D. Chiszar, H. Tanaka, Comstock Publishing Associates, Ithaca (1999)

11. M. Kenis, M.A. Auger-Rozenberg, A. Roques, L. Timms, C. Péré, M.J. Cock, C. Lopez-Vaamonde, Ecological Impacts of Non-Native Invertebrates and Fungi on Terrestrial Ecosystems (2009)

12. J.A. McNeely, L.E. Neville, P. Schei, J.K. Waage, World Conservation Union (IUCN) (2001)

13. J.M. Bullock, D. Chapman, S. Schafer, D. Roy, M. Girardello, T. Haynes, S. Beal, B. Wheeler, I. Dickie, Z. Phang, R. Tinch, K. Čivić, B. Delbaere, L. Jones-Walters, A. Hilbert, A. Schrauwen, M. Prank, M. Sofiev, S. Niemelä, P. Räisänen, B. Lees, M. Skinner, S. Finch, C. Brough, Final report: ENV.B2/ETU/2010/0037, Natural Environment Research Council, UK, (2010)

14. I. Béres, R. Novak, Zs. Pathy, G. Kazinczi, J. Agrofórum Extra (2006)

15. C. Bohren, C. Mermillod, N. Delabays, J. Plant. Dis. Prot., Special Issue (2006)

16. C. Patracchini, F. Vidotto, A. J.Weed Technol. (2011)

17. E. Gerber, U. Schaffner, A. Gassmann, H. Hinz, M. Seier, H. Müller-Schärer. J.Weed Researchv(2011)

18. E. Weber, D. Gut, Agron. Sustain. Dev. J. Dijon (2005).

19. T. Ke' Mives, I. Be' Res, P. Reisinger J. Weed Research and Technology (2006) -

20. L.P. Esipenko, A.S. Zamotailov J. Vestnik zachity rasteniy (2014) (Rus)

21. G. Kukorelli, P. Reisinger, M. Torma, T. J. Herbologia (2012)

22. C. Mlot, J. Biosience (1985)

23. L.D. Bradshaw, S.R. Padgette, S.L. Kimball, B.H. Wells, J. Weed Technol. (1997)

24. S. B. Powles, J. Pest Management Science (2008). 